\title{
The Caddo Nation Begins to Reassemble, 1840-1851
}

Jim Tiller

Unknown

Follow this and additional works at: https://scholarworks.sfasu.edu/ita

Part of the American Material Culture Commons, Archaeological Anthropology Commons, Environmental Studies Commons, Other American Studies Commons, Other Arts and Humanities Commons, Other History of Art, Architecture, and Archaeology Commons, and the United States History Commons

Tell us how this article helped you.

This Article is brought to you for free and open access by the Center for Regional Heritage Research at SFA ScholarWorks. It has been accepted for inclusion in Index of Texas Archaeology: Open Access Gray Literature from the Lone Star State by an authorized editor of SFA ScholarWorks. For more information, please contact cdsscholarworks@sfasu.edu. 


\section{The Caddo Nation Begins to Reassemble, 1840-1851 \\ Creative Commons License \\ (c) $($ ) $(9)$}

This work is licensed under a Creative Commons Attribution-NonCommercial 4.0 International License 


\section{The Caddo Nation Begins to Reassemble, 1840-1851}

\section{Jim Tiller}

\section{Introduction}

In July 1835 the Caddo Nation, which at the time was comprised of approximately 500 individuals, sold their Louisiana homeland to the United States and returned to their villages in eastern Harrison County, Texas where they remained until the opening of the Republic of Texas Land Offices in February 1838. At that point, deluged by squatters and Republic surveyors, the Caddo abandoned their villages and migrated to the prairies of frontier Texas. Approximately one-third of the tribe (some 165 individuals) under Chief Tsauninot returned to Shreveport in late September 1838 to collect the annuity for that year as called for in the land cession. Due to Indian wars then raging in Texas this group, hereafter referred to as the Shreveport Caddo, was unable to rejoin their fellow tribesmen in Texas.

During the early spring of 1840 the Shreveport band left their village(s) north of Cross Lake and migrated to Indian Territory, initially settling near Fort Towson. The removal of this group to Indian Territory opened a new phase in the history of the Caddo Nation, one that is beyond the interest of the author. That said, in developing material related to the Shreveport band's migration to modern-day Oklahoma a number of sources were examined that appear to contradict traditional 1840s Caddo history. For instance, it is very clear from the period literature that in October 1841 approximately one-half of that segment the tribe then residing in Texas, under the leadership of Chief Chonena (the father of later-Chief George Washington), secured permission from the Choctaw Nation to settle in Indian Territory. The Chonena/Washington and Shreveport bands at that point represented some two-thirds of the Caddo tribe (approximately 330 men, women and children). While these two groups appear to have lived in relative peace along the Boggy and Caddo Creek-Washita Rivers in presentday Oklahoma during the decade of the 1840s, they have been almost totally ignored by modern Caddo scholars.

The purpose of the material which follows is to place in the contemporary literature a number of sources that bear upon the reassembly of the Caddo Nation in Indian Territory during the 1840s. As the writer admittedly possesses relatively little knowledge of Oklahoma history and sources, perhaps any misinterpretations of the 1840-1850-period in Caddo history advanced within these pages will spur a colleague to correct my reading of the record.

\section{Sources}

1. 1840. May 22. Caddo Account with Charles A. Sewall \& Co.

Entry, Cash for ferriage, $\$ 22.00{ }^{1}$

2. 1840. August 28. Letter from Superintendent William Armstrong to Commissioner T. Hartley Crawford.

I am informed that there is in the neighborhood of Fort Towson about 100 of the Caddos.

They are from the neighborhood of Shreveport. ${ }^{2}$ 
3. 1841. May 26. Letter from Superintendent Armstrong to Commissioner Crawford.

The Caddos from Shreveport are now near the Washita waiting for the annuity of $\$ 10,000$ being the last due them. The balance of the tribe are on the Trinity and were to be in when the money should be paid which they expected I would bring with me from Washington. ${ }^{3}$

4. 1841. June 20. Report of Capt. B.D. Moore to Gen. Matthew Arbuckle.

The Caddoes numbering about two hundred men, women and children are located in the vicinity of Fort Towson. ${ }^{4}$

5. 1841. September 20. Letter from Superintendent Armstrong to Commissioner Crawford.

The majority of the tribe who are now in the Choctaw Nation on Kiamichi and Blue have not received any portion of the money, or if any, very little - those around Shreveport getting what little has been paid them in goods by the agent who received the money. ${ }^{5}$

6. 1841. October. The Chonena/Washington band is granted permission to settle in Indian Territory. ${ }^{6}$

7. 1841. November 6. Letter from Agent Charles A. Sewall to the Office of Indian Affairs.

Ex-Governor Butler writes me that the indemnity due the Caddo Indians remains in the Treasury recommended to be paid to the Indians individually. I have a claim against those Indians for about $\$ 4500$ which I will be unable to get if that course is adopted as that tribe is scattered in Arkansas and Texas. ${ }^{7}$

8. 1841. Late December (or early January 1842). Letters from Superintendent Armstrong to Commissioner Crawford.

I have therefore concluded to go to Red River and pay the Caddoes... I was detained at Boggy paying the annuity to the Caddoes. ${ }^{8}$

9. 1842. Late February. Statement of Gen. Ethan A. Hitchcock paraphrasing Chickasaw Agent A.M.M. Upshaw.

The Caddos were reduced he thought to about 250; that 167 were in the Choctaw Nation and that the last annuity due them was paid this year and now they are without a country and without an annuity and are living here by sufferance of the Choctaws. ${ }^{9}$

10. 1842. July 10. Letter from Chief Red Bear to the Muscogee Tribe.

I am with my people situated $1 / 2$ mile east of the Keachies in the Grand Prairie west of the Cross Timbers and south of Washita. With my people are the Tawakonees and Ionies, and we are all as one people ... As you know very well that we formerly have been on unfriendly terms with Texas and its citizens, but at length seeing and knowing our wrong ways, I determined to lay down the hatchet against all White and Red men and seek a country of peace. Accordingly, I crossed and settled north of Red River where we now are, and since that time have lived ourselves in peace and harmony ... our women have worked hard to make our little crops of corn which now is nearly in roasting ears. If we should leave our homes, the Texians would come and find our town evacuated and consequently consider us turned enemies and destroy our little crops which would be a great loss to us. ${ }^{10}$

11. 1842. August 18, 1842. Letter from James Riley to J.C. Spencer.

He [Pierce M. Butler, one of the Arkansas Indian agents] gave me the additional information that the Caddoes had been incorporated among the Chickasaws. ${ }^{11}$ 
12. 1842. August 15-24. Commissioners Stroud, Williams and Durst to Sam Houston.

We met four of the principal chiefs with other head men and warriors of four different tribes at a small Caddo village above the Chickasaw nation. ${ }^{12}$

13. 1845. April 8. Remarks by Lt. A.R. Johnston to the Sixth Annual Meeting of the Association of American Geologists and Naturalists.

After crossing the Washita at the Caddo village, the first strata of lime and sandstone bore S. $10^{\circ} \mathrm{E}$. and on the line of one outcrop of sand-rock was a belt of timber of the exact width of the stratum. A few miles further on, the strata became warped around until they stood east and west, and to the south a few miles was a high hill produced by the granite in its westward course. ${ }^{13}$

14. 1845. April 8. Map to Accompany Lt. A.R. Johnston's paper to the Sixth Annual Meeting of the Association of American Geologists and Naturalists (Figure 1). ${ }^{14}$

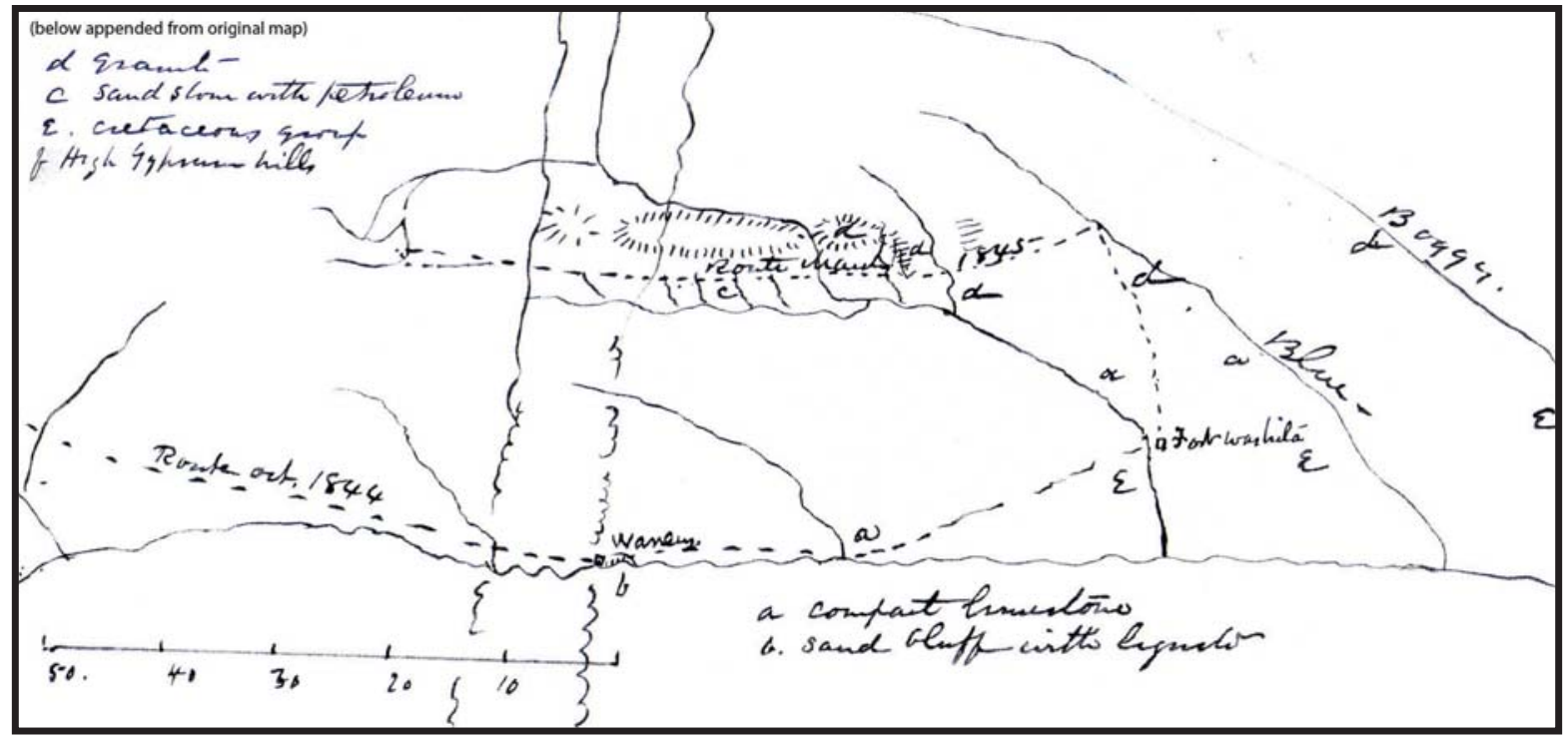

Figure 1. Sketch map, Lt. A.R. Johnston, $1845^{14}$.

15. 1845. August 16. Letter from Agent Upshaw to Superintendent Armstrong.

In the extreme western part of the Chickasaw District, there are several tribes, or parts of tribes, settled, which are generally called the wild Indians, viz: The Kechi, the Taw-a-ash, the Witchataw, the Wacoes, and on Washita, about ten miles from the [Chickasaw] agency [at Fort Washita], three-fourths of the Caddo Indians have settled. ${ }^{15}$

16. 1845. September 21. Letter from Superintendent Armstrong to Commissioner Crawford.

The Caddoes unlike the other bands mentioned, have no regular homes of their own. A few of them have settled among the Choctaws by permission of that tribe. They endeavor to support themselves by labor, the rest, like the Kickapoos, depend on the chase, and lead a wandering life. ${ }^{16}$ 
17. 1849. Topographical Map of the Road from Fort Smith, Arkansas to Santa Fe, New Mexico and from Dona Ana, New Mexico to Fort Smith (Figure 2). Map. 1849. Capt. R.B. Marcy. ${ }^{17}$ Marcy's map indicates the presence of a "Caddo vill" on the east bank of the Washita north of Fort Washita.

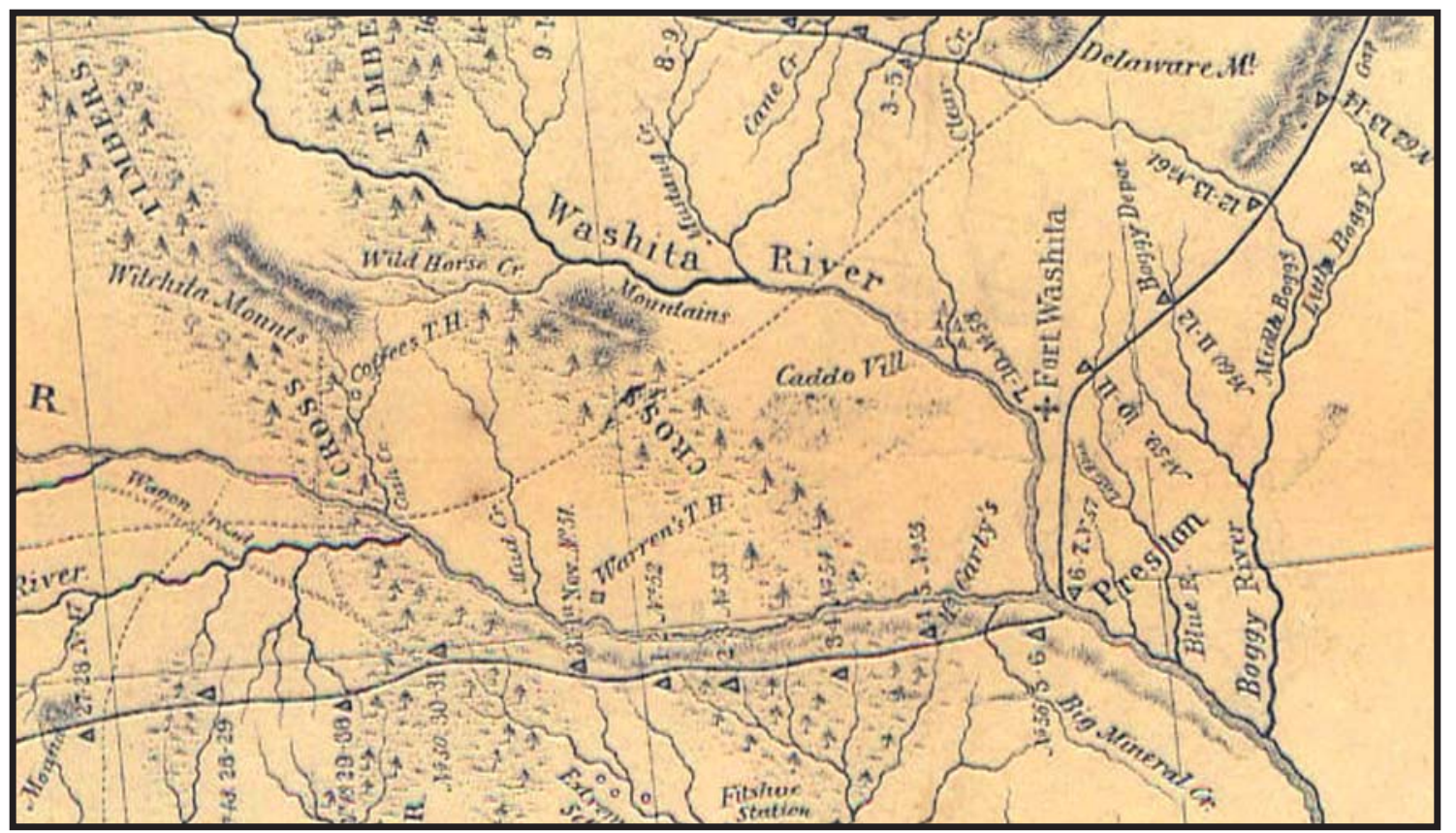

Figure 2. 1849. Capt. R.B. Marcy map, indicating presence of Caddo Village ${ }^{17}$.

18. 1849. November 10-16. From the Report of Lt. Nathaniel Michler.

We have passed several Indian villages, principally belonging to the Caddo and Bilusi tribes; they have settled down to raising corn, and with their cows and poultry seem quite domesticated. ${ }^{18}$

19. 1849. Reconnoissances of Routes from San Antonio de Bexar, El Paso Del Norte, etc. (Figure 3). Map. 1849. Lt. Nathaniel H. Michler. ${ }^{19}$ Michler's map depicts his route west out of Fort Washita (and south of Caddo Creek).

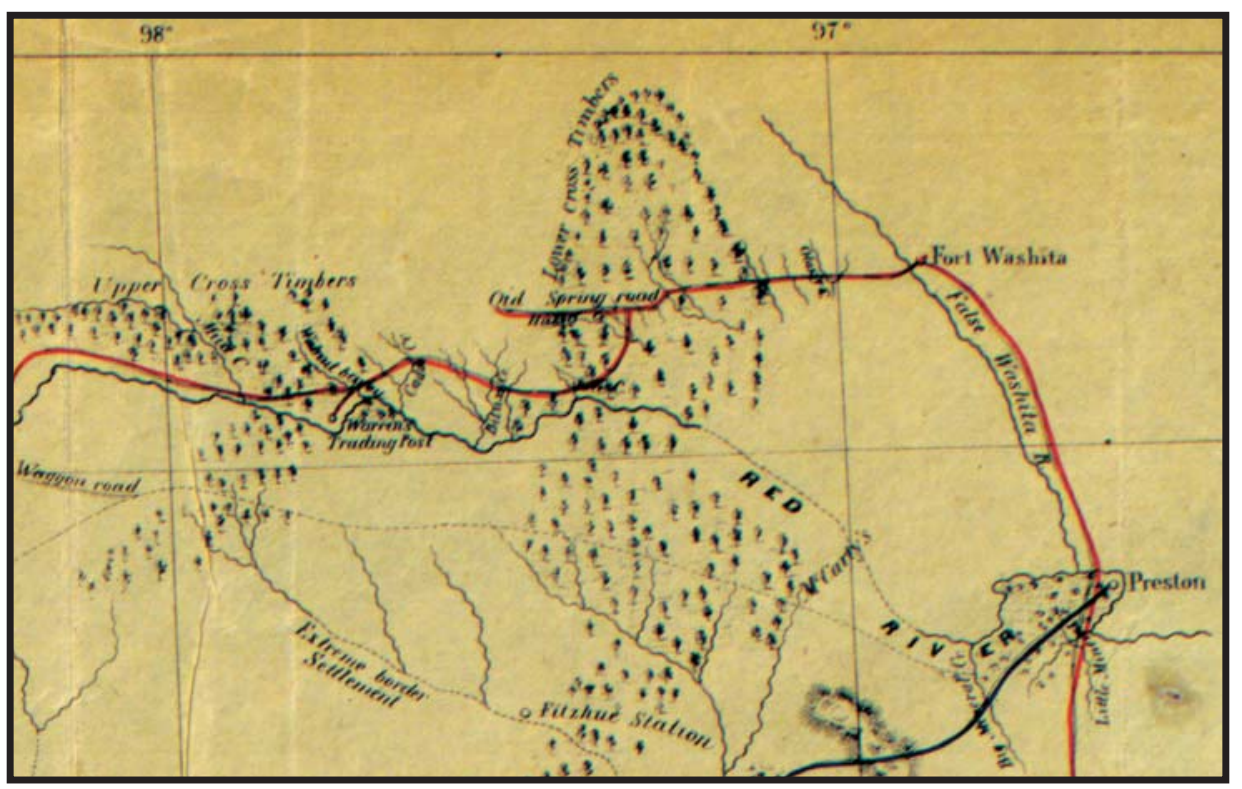

Figure 3. 1849. Lt. Nathaniel H. Michler. map. Caddo Villages were noted south of Caddo Creek $^{19}$. 
20. 1850. September 6. Memorial to the President of the United States from the Chickasaw General Council.

Your memorialists the Chickasaws in General Council assembled respectfully inform you that they are annoyed by the intrusion of bands of wild Indians who infest their District and commit many depredations upon them such as stealing their horses, hogs, cattle and other property ... Therefore we respectfully memorialize the President of the United States, our Great Father, to cause to be removed out of and to be permanently kept from within our limits, the Tonquarrays, Caddos, Keechies, Kickapoos, Quappaws, Boluxies, Cherokees, Shawnees Haynis, Wacoes and Wichitaws who are intruders upon them.... Be it further enacted that the Indians whose names are mentioned in the act of the Choctaw council approved October 1844 providing for the removal of some Indians in the Nation are excepted from the operation of resolutions. ${ }^{20}$

21. 1851. February 23. Col. Dixon Miles to Gen. Thomas Jesup.

Within this district [Fort Washita area] is located the Caddoes, about 300 in all, near the oil spring and not over 15 miles from where Capt. Marcy is ordered to locate a post on Wild Horse Creek [Fort Arbuckle]. They are disposed to cultivate the soil and live peaceably and friendly. ${ }^{21}$

22. 1851. June. Special Agent Jesse Stem to Commissioner Luke Lea.

While among the [Texas] Indians I endeavored to ascertain their exact numbers, and with this view induced the chiefs to go among their people and count them. Having no system of numbers, they enumerated only with their fingers, or by means of bundle of sticks. They brought me a bundle of sticks for each tribe... The following is the enumeration furnished me as above, which I consider very accurate [Caddoes, 161]. ${ }^{22}$

23. 1851. Map of the Country Between the Frontiers of Arkansas and New Mexico Embracing the Section Explored in 1849, 50, 51 and 52. Map (1852). Capt. R.B. Marcy. ${ }^{23}$ Marcy's map indicates the presence of an "old Caddo village" on Pennington Creek near present-day Tishomingo (Figure 4).

24. 1851. September 22. Chickasaw Agent Kenton Harper to Commissioner Lea.

It appears that one of the tribes [George Washington's Caddo band] has heard of the complaint made against them ... [that Chonena had asked for and was granted] a strip of country on the Washita, about thirty miles above this, where the portion of the tribe that kept together now live. [Harper continued that he] had just learned though, that they were not all exactly on the land that was assigned them - that some of them were living on the other side of the river. This was not right nor would it be allowed. They must keep within their limits ... The character I get of these people from Chickasaws who know them best is that they are well disposed and remarkably honest for Indians who pursue so old a life. Indeed some of the Chickasaws contend that their presence so far has been rather a benefit - that they have served to check the inroads of other wild tribes of less scrupulous habits and that they would be sorry to see them removed. The number of Caddos now settled together, I could not satisfactorily ascertain; but it is small, from three hundred to four hundred. A portion of the tribe is among the Choctaws on Boggy, and I understand they are industrious, worthy people. ${ }^{24}$ 
25. 1883. January 22. Testimony of George Washington before the General Council of the Wichita Indians and other affiliated tribes.

I am 70 years old. I came with my people from Louisiana to Texas, where we remained until the war with Mexico. We were then invited by one of the principal chiefs of the Choctaws to come up to their country, and about one-half of my people accepted the invitation and moved up into the Choctaw country and settled on Caddo Creek. After the war we were asked to go to Houston to have a council, and my people went there, and at that council a treaty of peace was made, and afterwards we came back to the Choctaw country on Caddo Creek, where we remained until the council at Arbuckle in $1859 .{ }^{25}$

\section{Summary Comments}

Cecile Carter devoted a substantial part of the final chapter of her book to the reflections of 78 year old (in August 1979) Julia Edge, who suggested that after the land cession the Caddo left ("started out from") their East Texas homeland in three distinct waves. ${ }^{26}$ Are these three migrations from Louisiana the same as the three migration waves into Indian Territory described in the above paragraphs? That's hard to say. Almost surely the group Ms. Edge identified as the Kiamichi band was the Shreveport Caddo who we know initially settled on the Kiamichi River near Fort Towson in 1840. Very probably the "Whitebead bunch" was the Chonena/ Washington band - certainly Washington was known to be a Whitebead in his later years. While this band did not come directly from East Texas to Louisiana as suggested by Ms. Edge, they did initially settle along the lower Washita River in the fall of 1841. Finally we have the third group Ms. Edge described as having gotten "lost in the mountains." The reader will note that Ms. Edge did not offer a name for the band remaining in Texas after 1841. Were they the group that "got lost in the mountains?" Possibly, if we interpret "lost in the mountains" as "lost" to the majority of the tribe up until they were reunited with the Indian Territory Caddo on Sugar Creek in the late summer of 1859.

A lot of questions remain regarding the early history of the Caddo in Indian Territory. 


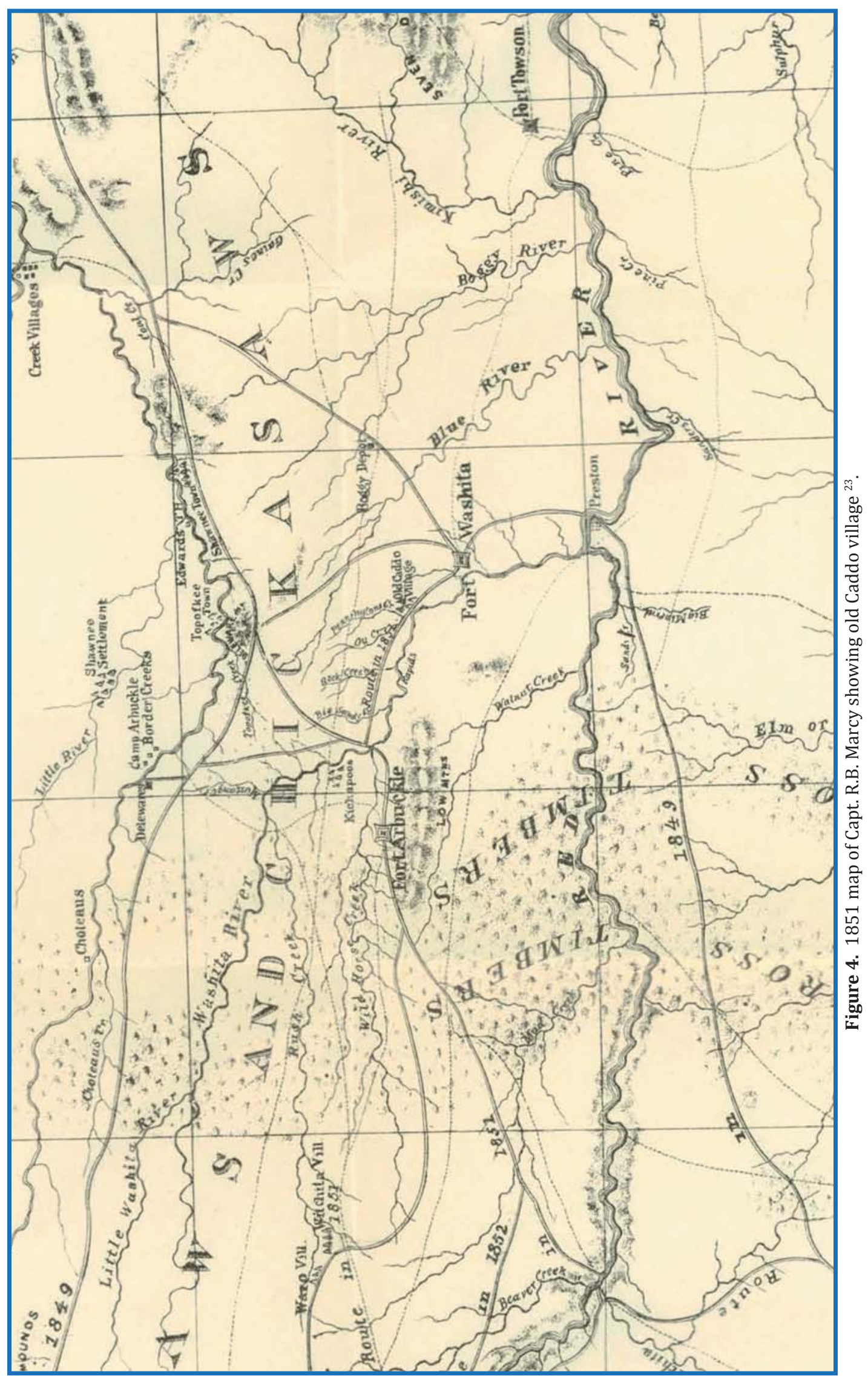




\section{Endnotes}

\section{Abbreviations}

1035 - 27th Cong., 2nd sess. House Report 1035.

LRCaddo - Letters Received by the Office of Indian Affairs, 1824-1880. Caddo Agency. Roll 31. National Archives and Records Administration. Washington, DC.

LRRed - Letters Received by the Office of Indian Affairs, 1824-1880. Red River Agency. Roll 727. National Archives and Records Administration. Washington, DC.

LRWestSuper - Letters Received by the Office of Indian Affairs, 1824-1880. Roll 923. Western Superintendency, 1832-1851. National Archives and Records Administration. Washington, DC.

TillerVol.2. Tiller, Jim. Before the Line. Vol. 2, Letters from the Red River, 1809-1842. Huntsville, YX: The START Group, 2012.

$* * * * * *$

1. Sewall, Charles A. \& Co. Account of Caddo Indians. December 29, 1839 through July 9, 1841. LRCaddo (same as TillerVol.2, Item 634). The July 9 entry was the last item directly associated with the Caddo in the books of Shreveport merchant Charles Sewall. This was almost surely a bill paid upon receipt from the ferryman for work previously chargeable to the tribe. The majority of the entries in the Caddo account were from midFebruary to mid-March. The date of the last trade goods sold on the account was April 21.

2. Armstrong, William. Letter to T. Hartley Crawford, Commissioner of Indian Affairs. August 28, 1840. LRCaddo (same as TillerVol.2, Item 642). With so few documents available, any attempt to distinguish one band from another requires the reader to give careful consideration to dates, location and the number of Caddo referenced by period writers. Certainly the numbers provided by these writers do not always match the groupings suggested. It is a given that each group was likely comprised of several bands, and it appears from available estimates the bands did not remain together in every instance. Assuming the Shreveport band was comprised of approximately 165 individuals (see below), it is not clear where the balance of this group made their home during the 1840 crop year although, based on numbers alone, it is apparent they were not all in the Fort Towson area.

Regarding the population of the Caddo Nation in the late 1820s-early 1830s period: (1) Agent Gray's October 1824 census noted a population of 450;.1. (2) Col. Many's January 1835 report stated that the Caddo population "cannot exceed 600;"2.2 (3) in June 1835, Commissioner Brooks estimated the population of the Caddo Nation on the treaty grounds at 489 men, women and children. ${ }^{2.3}$ It is probably safe to say that approximately 500 Caddo were expelled from eastern Harrison County in late February 1838.

The number of individuals in Tsauninot's band (the Shreveport Caddo) was estimated at between 100 and 166. It is likely that the band was comprised of approximately 165 individuals. ${ }^{2.4}$

Assuming the Shreveport Caddo numbered 165, the two-thirds of the tribe that did not return to Shreveport in the fall of 1838 but who remained on the western prairies (the Texas Caddo) would have numbered approximately 330 in the late 1830 s and early 1840 s. $^{2.5}$

Caddo chief George Washington testified in 1883 that approximately one-half (165) of the Texas Caddo (the Chonena/Washington band) separated themselves from that group and migrated to Indian Territory in late $1841 . .^{2.6}$

Thus by early 1842, the Caddo Nation was divided into three distinct bands, each comprised of approximately 165 individuals.

2.1. Gray, George. Letter to Thomas McKenney, Superintendent of Indian Affairs. October 1, 1824. LRRed (same as TillerVol.2, Item 302). 


\section{Endnotes (cont.)}

2.2. Many, Col. James B. Letter to D. Kurtz, Acting Commissioner of Indian Affairs. January 6, 1835. LRCaddo (same as TillerVol.2, Item 569).

2.3. 1035. p. 116. It is not possible to accurately determine the Caddo population in the late 1830 s. While a figure of 1000 was suggested in testimony provided in the Grappe matter as being in attendance at the land cession, ${ }^{2.3 .1}$ based on several later estimates this figure almost surely indicates that in addition to the Caddo a number of non-Caddo Indians were also in attendance at the 1835 treaty signing.

2.3.1. 1035. p. 85. Brooks indicated in the Treaty Journal (1035. p. 116) that precisely 489 men, women and children assembled on the treaty grounds on June 25 , the day before the treaty council was convened.

2.4. In January 1840, T.G.H. Scott estimated the Shreveport Caddo band to number "at this time not exceeding one-fourth of the said Caddo tribe of Indians in the United States.".4.1 In January 1839, a statement was made in conjunction with Gen. Thomas Rusk's "invasion" of Shreveport in which the Shreveport Caddo were estimated to number 166. 2.4.2 Col. Many's report in April 1839 estimated this same band to number $162 .{ }^{2.43}$ H.G. Rind, the emissary sent by William Armstrong to assess the situation of the Caddo, estimated the number of Shreveport Caddo at 160. . $^{2.44}$

2.4.1. Scott. T.G.H. Statement Protesting the Meeting of Tsauninot and others with H.G. Rind. January 23, 1840. LRCaddo (same as TillerVol.2, Item 631/637).

2.4.2. Citizens of Shreveport. A Statement of the Facts Connected with the Recent Outrage Perpetuated by General Thomas J. Rusk of the Army of Texas by his Invasion of the Territory of the United States. January 8, 1839. LRCaddo (same as TillerVol.2, Item 616).

2.4.3. Many, Col. James B. Letter to Joel R. Poinsett, Secretary of War. April 19, 1839. LRCaddo (same as TillerVol.2, Item 621).

2.4.4. Rind, H.G. Letter to William Armstrong, Superintendent of Indians, West. February 5, 1840. LRCaddo (same as TillerVol.2, Item 632/633).

2.5. In an August 28, 1849 letter to T. Hartley Crawford, Commissioner of Indian Affairs, William Armstrong, Superintendent for the Western Territory, said of the Texas Caddo band

I am satisfied that with Tarshar there are perhaps one-half if not more of the tribe. ${ }^{2.5 .1}$

In March 1841, Armstrong observed

that the Caddo of Texas, who have not participated in the annuity ... constitute at least twothirds or three-fourths of the tribe. ${ }^{2.5 .2}$

2.5.1. Armstrong, William. Letter to T. Hartley Crawford, Commissioner of Indian Affairs. August 28, 1840. LRCaddo (same as TillerVol.2, Item 642). In this same letter, Armstrong estimated the Shreveport band, then at Fort Towson, to number about 100.

2.5.2. Armstrong, William. Letter to T. Hartley Crawford, Commissioner of Indian Affairs. March 5, 1841. LRCaddo (same as TillerVol.2, Item 653).

2.6.The accuracy of Washington's estimate was generally confirmed by Jesse Stem, Special Agent for the Indians of Texas in June 1851 (see Endnote 25).

3. Armstrong, William. Letter to T. Hartley Crawford, Commissioner of Indian Affairs. May 26, 1841. LRCaddo (same as TillerVol.2, Item 654). Clearly Armstrong (who had only recently returned from Washington) was not aware of the 200 Caddo then in residence near Fort Towson (see Endnote 4). His reference to the Shreveport Caddo being "near the Washita" is very likely based on information he had about that band before he left for Washington during the winter of 1840-1841. ${ }^{3.1}$ For additional sources regarding the possible location of Shreveport Caddo settlements in the 1840-1842 period, see Endnotes 4, 5, 9, 10, 11, 24 and 25. 


\section{Endnotes (cont.)}

3.1. It is the view of the writer that the Shreveport Caddo moved west from the Fort Towson area (see again Endnote 2), probably to the Blue and/or Washita Rivers, during the winter of 1840-1841. This belief is based on the fact that Armstrong almost surely left Indian Territory for Washington shortly after January 28, 1841..$^{3.1 .1}$ He was in Washington at least as late as March 30 of that year ${ }^{3.1 .2}$ which means he most likely did not return to the Choctaw Agency until the first part of May. His belief that the Shreveport Caddo were "near the Washita" and the "balance of the tribe are on the Trinity" (as opposed to being around Fort Towson (see Endnotes 4, 5 and 6) indicates he had no knowledge of the presence of the 200 or so Caddo then living around Fort Towson. Thus the writer assumes that his knowledge of the Shreveport Caddo residing near the Washita was probably based on information he had of the tribe prior to his having left Indian Territory in late January-early February 1841.

3.1.1. Armstrong, William. Letter to unknown recipient. January 28, 1841. LRWestSuper.

3.1.2. Armstrong, William. Letter to T. Hartley Crawford, Commissioner of Indian Affairs. March 30, 1841. LRWestSuper.

4. Moore, Capt. B.D. Letter to Gen. Matthew Arbuckle. June 20, 1841. LRWestSuper. The 200 Caddo were probably comprised of members of the Texas band who had come to Indian Territory to collect the final annuity. ${ }^{4.1}$ The Chickasaw frontier was so unsettled during the spring of 1841 that a general Indian war was threatened. ${ }^{4.2}$ If a segment of the Texas band had come to the area that spring expecting to receive payment, they may well have chosen to make their temporary camp near Fort Towson so as not to be mistaken for more hostile groups to the west.

4.1. Armstrong, William. Letter to T. Hartley Crawford, Commissioner of Indian Affairs. March 5, 1841. LRCaddo (same as TillerVol.2, Item 653).

4.2. The following from LRWestSuper: Upshaw, A.M.M. Letter to Gen. Matthew Arbuckle. February 5, 1841; Armstrong, William. Letter to T. Hartley Crawford, Commissioner of Indian Affairs. March 30, 1841.

5. Armstrong, William. Letter to T. Hartley Crawford, Commissioner of Indian Affairs. September 20, 1841. LRCaddo (same as TillerVol.2, Item 656). Because Armstrong did not bring the final annuity with him when he returned from Washington in the spring, it appears a substantial segment of the Texas Caddo may have remained in Indian Territory until late December-early January 1842 when Armstrong was finally able to make the payment (see Endnote 8). His comment regarding the "majority of the tribe" appears to be a reference to the 200 members of the Texas band (see again Endnote 4) and the Shreveport band on the Blue River (see again Endnote 3). At this point the Chonena/Washington band had not secured permission to settle in Indian Territory (see Endnotes 24 and 25).

6. Harper, Kenton. Letter to Luke Lea, Commissioner of Indian Affairs. September 22,1851. Letters Received by the Office of Indian Affairs, 1824-1881. Chickasaw Agency. Roll 140. National Archives and Records Administration. Washington, DC; 48th Cong., 1st sess. Senate Executive Document 13. p. 34. See Endnotes 24 and 25.

7. Sewall, Charles A. Letter to the Office of Indian Affairs. November 6, 1841. LRCaddo (same as TillerVol.2, Item 665/666). See again Endnote 2.4.1. Sewall's concern here was solely with the Shreveport Caddo. It was to this group that he had paid the 1838 and 1839 annuities and probably advanced goods against the anticipated 1840 annuity. His reference to Arkansas is almost surely to Miller County, Arkansas which at one time had extended into southeastern Oklahoma and northeastern Texas. 


\section{Endnotes (cont.)}

8. The following from LRWestSuper: Armstrong, William. Letter to T. Hartley Crawford, Commissioner of Indian Affairs. December 21, 1841; Armstrong, William. Letter to T. Hartley Crawford, Commissioner of Indian Affairs. January 25, 1842. In these two letters, Armstrong indicated his intention to pay the Caddo their fifth and final annuity (letter of December 21), and the fact he did pay them (letter of January 25). At this point the Caddo were on their own - no land of their own, and no more payments from the government.

9. Hitchcock, Gen. Ethan A. Hitchcock (edited and annotated by Grant Foreman). A Traveler in Indian Territory: The Journal of Ethan Allen Hitchcock, Late Major-General in the United States Army. Norman, OK: University of Oklahoma Press, 1996. p. 181. From this statement it appears that at the time Superintendent Armstrong paid the final annuity to those segments of the tribe then in Indian Territory in late December 1841 or early January 1842, the Texas, Chonena/Washington and Shreveport Caddo bands were not united. The 167 Caddo then in the Choctaw Nation (as opposed to the recently approved Chickasaw District lying east of the Washita, a fine distinction Agent Upshaw would almost surely have been sensitive to and likely noted in his comments to Hitchcock) were almost exactly the number of Shreveport Caddo known to have migrated from Shreveport in the spring of 1840. Upshaw was very precise in his count of these Caddo - not 150, 160 or even 165, but exactly 167. As Upshaw had been responsible for overseeing this band for almost two years, it is very likely he had considerable first-hand knowledge of the Shreveport band. One can only wonder who and where the other 83 Caddo were. No mention is made of the Chonena/Washington or Red Bear band(s) which by this time were living in Indian Territory (see Endnote 10).

10. Red Bear. Letter to the Muscogee Tribe. July 10, 1842. LRCaddo (same as TillerVol.2, Item 673). The Red Bear band was clearly living on the Grand Prairie north of the Red River. In fact, later comments by Red Bear indicate that at the time the above was written he was probably living at the Tawehash village near the head of Cache Creek..$^{10.1}$ Was the Red Bear band part of the missing 83 Caddo of the Chonena/Washington band noted by Upshaw (see again Endnote 9)? The answer is probably yes. Notice in the comments of Red Bear the women have "little crops of corn which is now nearly in the roasting ears." The stage of the corn crop and the work that would have been necessary to prepare the fields for planting suggest the Red Bear band had been living in the Tawehash village since late winter of 1841 or very early spring of 1842 , very near to the time Hitchcock was passing through the Chickasaw District.

10.1. Winfrey, Dorman H. and James M. Day. The Indian Papers of Texas and the Southwest, 1825-1916. Vol. II. Austin, TX: The Pemberton Press, 1966. p. 42. Tawehash (Taovayas) are names associated with the principal tribe of the Wichita Confederacy. The writer assumes, based on Red Bear's statements on the subject and the known presence of both old Keechi and Wichita ${ }^{10.1 .1}$ settlements in close proximity to the Cross Timbers-Grand Prairie contact zone, that in July 1842 the Red Bear band was located at the eastern end of the Wichita Mountains north of Cache Creek near modern-day Fort Sill.

10.1.1. 32nd Cong., 2nd sess. Senate Executive Document 54. Map on un-numbered page. See Marcy's description of the immediate area of the villages on p. 72.

11. Annual Report of the American Historical Association for the Year 1907. Vol. II, Diplomatic Correspondence of the Republic of Texas. Washington, DC: Government Printing Office, 1908. p. 594. With this comment, Riley confirmed that at least some of the Caddo tribe had found a home among the Chickasaws. 


\section{Endnotes (cont.)}

12. Winfrey, Dorman H. and James M. Day. The Indian Papers of Texas and the Southwest, 1825-1916. Vol. I. Austin, TX: The Pemberton Press, 1966. p. 139. It is not possible to say if the village mentioned was in fact located above the Chickasaw District proper or if this is a reference to a location above areas then settled by the Chickasaw. Period accounts of the meeting are in conflict. A September 3, 1842 account in the Northern Standard newspaper indicated the "treaty of friendship was concluded in the Grand Prairie." ${ }^{12.1}$ A week later the same newspaper carried an article, seemingly written as a first-hand account, that stated "This desirable object [the treaty] was effected at the Chickasaw Depot in the Chickasaw Nation." ${ }^{12.2}$

12.1. Northern Standard. Newspaper. Clarksville, Red River County, Texas. September 3, 1842.

12.2. Northern Standard. Newspaper. Clarksville, Red River County, Texas. September 10, 1842.

13. Johnston, Lt. A. R. "Remarks on the Geology of the Vicinity of Fort Washita." Abstract of the Proceedings of the Sixth Annual Meeting of the Association of American Geologists and Naturalists. New Haven, CT. April, 1845. p. 75-77. The original text sent by Johnston to the Association for presentation/publication is dated April 8, 1845. Collection 305, Box C:T-D, Folder 11. Academy of Natural Sciences, Philadelphia, PA. The geology described in Johnston's statement should be of some assistance in determining the approximate location of the Caddo village on the Washita north of Caddo Creek (see Endnote 14 for the map of Johnston's route of return to Fort Washita).

14. Johnston, Lt. A. R. Map Accompanying Johnston's "Remarks on the Geology of the Vicinity of Fort Washita." Abstract of the Proceedings of the Sixth Annual Meeting of the Association of American Geologists and Naturalists. New Haven, CT. April, 1845. p. 75-77. Collection 305, Box C:T-D, Folder 11. Academy of Natural Sciences, Philadelphia, PA. Clearly Johnston's return route to the Washita took him north of Caddo Creek. Whether the Caddo village mentioned in his report (see again Endnote 13) was on the east or west bank of the Washita remains to be archeologically determined, however, it appears the site may well be found on the west side of the river (see Endnote 24).

15. 29th Cong., 1st sess. Senate Document 1. p. 525. In his letter, Upshaw sequentially described first the eastern Chickasaw District and then the Cross Timbers and finally the western portions of the District. The above statement describing the location of the Caddo on the Washita some 10 miles from the Chickasaw Agency, coming as it does after his description of the eastern Chickasaw District and Cross Timbers, seems to place the majority of the Caddo then under his jurisdiction to the west of the Washita River with the "wild" Indians. By inference (see Endnotes 16 and 24), the balance of the tribe, i.e., the remnants of the Shreveport Caddo, were probably located on the Blue and Boggy Rivers in Choctaw country.

16. Armstrong, William. Letter to T. Hartley Crawford, Commissioner of Indian Affairs. September 21, 1845. LRWestSuper; same as 29th Cong., 1st sess. Senate Document 1. p. 508. This statement suggests that the majority of the Caddo, like the roving Kickapoos, "lead a wandering life" as distinguished from the more sedentary segment of the tribe (probably the Shreveport Caddo) then settled among the Choctaws.

17. 31st Cong., 1st sess. House Executive Document 45. p. 77 and the un-numbered page for the map. At the time Marcy compiled his 1849 map, he had not visited the Caddo village on Pennington Creek (he had only gotten as close as Fort Washita. See page 77 for his account while in the area) and thus his notation as to the village's location was very likely based on second-hand information. 


\section{Endnotes (cont.)}

18. 31st Cong., 1st sess. Senate Executive Document 64. p. 32. This statement, along with Michler's map (see Endnote 19) confirms the presence of Caddo villages on the west side of the Washita south of Caddo Creek. These villages almost surely belonged to the Chonena/Washington band (see Endnote 24).

19. 31st Cong., 1st sess. Senate Executive Document 64. Map (p. 252). This map is also available as Reconnoissances of Routes from San Antonio de Bexar to El Paso del Norte. 1849. Lt. W.H.C. Whiting, United States Topographical Engineers. Map Number 1529, Map Collection. Texas State Library and Archives Commission. Archives and Information Services Division. Austin, Texas. Michler's route as depicted on his map confirms the presence of Caddo villages on the west side of the Washita south of Caddo Creek (note his route, the direction of stream flow south to the Red River and the location of Hickory Creek).

20. Chickasaw General Council. Memorial to the President of the United States Regarding Intruders. September 6, 1850. Letters Received by the Office of Indian Affairs, 1824-1881. Choctaw Agency. Roll 171. National Archives and Records Administration. Washington, DC. While the Caddo were enumerated in the memorial itself, the Chickasaws were careful to except those tribes (including the Caddo) who had by an earlier Council been granted permission to occupy their lands.

21. Foreman, Grant. The Five Civilized Tribes - Cherokee, Chickasaw, Choctaw, Creek, Seminole. Norman, OK: University of Oklahoma Press, 1934. p. 128. This comment by Miles seems to suggest that the Caddo were clustered "near the oil spring" (now under the lake on modern-day Goddard Ranch). Such a location would place them on the east side of the Washita River almost due east of the modern community of Gene Autry. The fact the Chickasaws only a few months before (see again Endnote 20) suggested at least a part of the tribe was on the west side of the river may indicate that the 300 were settled on both sides of the Washita in the general area of Caddo Creek. If that were the case, then those to the east of the Washita near the oil spring itself would probably have been there in contravention of the original permission given them by the Chickasaws (see Endnote 24).

22. 32nd Cong., 1st sess. Senate Executive Document 1, Part 3. pp. 522-523. Despite what were doubtless any number of cross-Red River movements, the number of Caddo in the Texas band appears to have held remarkably stable across the decade of the 1840s. One can but wonder what caused this segment of the tribe to remain in Texas. After all, the Shreveport and Chonena/Washington bands, representing some two-thirds of the tribe, had been living in relative peace in Indian Territory at the invitation of the Choctaws since late 1841.

23. 32nd Cong., 2nd sess. Senate Executive Document 54. Map (un-numbered page). In his route north out of Fort Washita in 1851, Marcy indicated he passed through an "old Caddo village" on Pennington Creek near present-day Tishomingo. (see http://www.unco.edu/library/gov/middle ground/Maps/calhoun4.pdf) This is doubtless the same village he noted on his 1849 map (see again Endnote 17). Interestingly, Marcy did not comment on the presence of a Caddo village on either the east or west bank of the Washita in the area of Caddo Creek (see again Endnotes 13, 14 and 21) even though, at least according to Dixon Miles, there were at the time some 300 or so Caddo located in the general vicinity of the oil spring (on Goddard Ranch). This suggests that the village noted by Johnston (see again Endnote 14) may have been located on the west side of the Washita. 


\section{Endnotes (cont.)}

24. Harper, Kenton. Letter to Luke Lea, Commissioner of Indian Affairs. September 22, 1851. Letters Received by the Office of Indian Affairs, 1824-1881. Roll 140 Chickasaw Agency. National Archives and Records Administration. Washington, DC. It appears from the statements made by Chief George Washington to Harper (1851) and later (1883) to the General Council of the Wichita Indians and other affiliated tribes (see Endnote 25) that at the time the Choctaw granted the Caddo the right to settle upon their lands, they considered the Shreveport and Chonena/Washington bands as separate entities. Were the two bands granted permission to settle separately the Shreveport Caddo on the Blue and/or Boggy River and the Chonena/Washington band on the Washita? The record is not clear, although it appears that in fact they may well have been (see Endnote 25). ${ }^{24.1}$

24.1. It is the view of the author that the Choctaw probably gave the Chonena/Washington band permission to settle west of the Washita along Caddo Creek as noted by George Washington (see Endnote 25). Consider that in September 1850 the Chickasaws had petitioned the United States to remove a number of intruding bands, including the Caddo, from west of the Washita (see again Endnote 20). It was likely this petition that moved Chief Washington to meet with newly appointed Chickasaw Agent Harper to prove the case that his tribe had the right to settle west of the Washita. The fact Harper indicated that "they were not all exactly on the land that was assigned them - that some of them were living on the other side of the river" seems to suggest that those on the east side of the river around the oil spring proper (see again Endnote 21) were in fact out of their assigned area.

25. 48th Cong., 1st sess. Senate Executive Document 13. p. 34. Washington's statement, when combined with comments attributed to him by Harper (see again Endnote 24), make it clear that the Chonena/Washington band came to Indian Territory in the fall of 1841 at the invitation of Choctaw District Chief George Folsom, and that the band was given permission to settle on Chickasaw lands. There is very little period material the author is aware of that can be construed as relating to the Shreveport band that places that group anywhere except on Blue River, Boggy River or possibly in the Fort Towson area. It is appears the villages and settlement concentrations described by Stroud (see again Endnote 12), Johnston (see again Endnotes 13 and 14), Upshaw (see again Endnote 15) and Marcy (see again Endnotes 17 and 23) were probably established by the Chonena/ Washington band and, for reasons unknown, they were likely east of the boundaries established for them by the Choctaw). These villages appear to have been abandoned by the late 1840s in favor of sites on the west side of the Washita (see again Endnotes 18 and 19). ${ }^{25.1}$

25.1. There is a town in modern-day Bryan County named Caddo. To those familiar with the history of this area, the presence of such a name must seem a bit odd - sort of like a town in East Texas being named Navajo. The Encyclopedia of Oklahoma History and Culture indicates the town was

named for the nearby Caddo Hills, site of an 1808 battle between the Caddo and Choctaw, in a low range of hills two miles southeast of the town..$^{25.11}$

The author suspects a detailed history of the tribe in Indian Territory will probably determine that the area in the vicinity of the Caddo Hills was the home of the Shreveport Caddo band in the years following their migration to Oklahoma. Interestingly, one of the sources cited by the Encyclopedia was Cullberson's "Indian Against Indian" article in the June 1929 Chronicles of Oklahoma. In the article, Cullberson, who apparently relied heavily on the personal recollections of Cornelius Jones (born in 1837), recounts how

Some fifteen years after the Choctaws removed to this country they organized themselves, so as to rid their country forever of these horse stealers [the Caddo]. ${ }^{25.1 .2}$ 


\section{Endnotes (cont.)}

While the author's survey of the Oklahoma literature was admittedly superficial, no evidence was found for the Choctaw removing the Shreveport Caddo from their lands during the 1840s. In fact, as late as September 1851 Chickasaw Agent Harper in describing the Caddo in Indian Territory noted that A portion of the tribe is among the Choctaws on Boggy, and I understand they are industrious, worthy people..$^{25.13}$

More likely, based on the author's experience with recollections, the story recounted to Cullberson

probably contains the seeds of the reason for the abandonment of Marcy's "old Caddo village" on Pennington Creek near Tishomingo.

25.1.1. Brimage. Lucille. "Caddo." Encyclopedia of Oklahoma History and Culture. Published online by the Oklahoma Historical Society.

25.1.2. Cullberson, James. "Indian Against Indian." Chronicles of Oklahoma. Vol. 7, No. 2 (June 1929). p. 165.

25.1.3. Harper, Kenton. Letter to Luke Lea, Commissioner of Indian Affairs. September 22, 1851. Letters Received by the Office of Indian Affairs, 1824-1881. Chickasaw Agency. Roll 140. National Archives and Records Administration. Washington, DC.

26. Carter, Cecile Elkins. Caddo Indians: Where We Come From. Norman, OK: University of Oklahoma Press, 1995. p. 356. 